\title{
The Framework for Restitution/Compensation Process in Albania
}

\author{
Saida Bejtja (Muca) \\ "Aleksander Xhuvani" University. Faculty of Educational Sciences, \\ Department of Civic Education. Elbasan, Albania. \\ E mail: saida.muca@live.com \\ Dritan Bejtja \\ "Aleksander Xhuvani" University. Faculty of Educational Sciences, \\ Department of Civic Education. Elbasan, Albania.
}

\section{Doi:10.5901/ajis.2013.v2n8p291}

\begin{abstract}
The property restitution legislation which is currently in force provided for the establishment of the State Committee on Property Restitution and Compensation, which was composed of politically nominated members of both majority and opposition parties, as well as the President's office. The composition had to finally be approved and appointed by the Albanian Assembly. Commissions composed by the same rules were also foreseen at regional level. However, their structure was seen as an obstacle to the efficiency of the restitution process. Thus, in 2006, an amendment to the law provided for the replacement of the commissions with individual administrative institutions, namely the Property Restitution and Compensation Agency and its regional offices. Twelve such regional offices were in place up to January 2010, when a new amendment to the law abolished them. As from February 2010 only the central agency deals with the property restitution and compensation process. The Ministry of Justice and the institutions of the Prime Minister are in charge of the control and management of this agency, including the appointment of its leader. The organisation of the national agency is regulated by Decision 566/2006 of the Council of Ministers, on the organisation and functioning of the Property Restitution and Compensation Agency. Each regional agency has five to eleven employees who are now going to be transferred to the national agency in Tirana. However, the restructuring process still has a long way to go. The draft regulations for the central agency need to take into account a detailed consideration of the number of claims seeking a resolution, as well as the property restitution deadline which has been set for the end of 2011.
\end{abstract}

Keywords: property, restitution, legislation, compensation, process.

\section{Introduction}

The process of restitution and compensation of property in Albania started from the moment the communist regime vanished away in order to establish a pluralist regime that began with the recognition of property rights and free private initiative. The process of property restitution and compensation was an obligation that all properties expropriated subjects during the previous dictatorial regime should return to become even though this was not possible and compensation to owners.

The evolving process of property restitution and compensation is:

Adoption of Law No. 7698, dated 15.04.1993 "On restitution and compensation of property to former owners" and the creation of committees for restitution and compensation of property in the municipality of the former District Councils, given as recognition of the right competencies property restitution or compensation to the expropriated subjects.

Law no. 7698 was repealed, dated 15.04.1993 with the approval of Law no. 9235, 61 29.7.2004 "On restitution and compensation of property" where the state committee was set restitution and compensation of property which functioned as a collegial body, together with local committees of return and compensation in circuit country.

In the period of 2009 the process of property restitution and compensation were hampered by reason of abolition of the regional offices of restitution and compensation of property in the counties where the procedural decisions on property restitution and compensation will be completed in the Albanian capital Tirana.

Period of 2011 marked the beginning application of a new form of compensation which was in cash compensation, but was partially applicable for limited period of time due to time citeria, the surface or the other criteria. 


\section{Law on restitution and compensation of immovable property}

The right to property is provided in the Albanian Constitution of 1998 (Art. 41) ${ }^{1}$, which also set a deadline of two to three years, after its entry into force, for the Assembly to adopt laws for the just resolution of different issues related to expropriations and confiscations done before the approval of the Constitution (Art. 181.1). The Law on Restitution and Compensation ${ }^{2}$ which is currently in force, was adopted in 2004, three years after the abovementioned deadline had passed (e.g. on 3.10.2002 in Resolution No.1 the Assembly requested the Special Committee for Property to speed up the drafting process) $)^{3}$, after OSCE had brought together the Socialist Party (SP), the Democratic Party (DP) and the Republican Party in a common technical working group on the draft law (Venice Commission 2004, OSCE Presence in Albania). The law was expected to provide for legal security by regulating property relationships in a final way. In the meantime, however, it has been amended four times ${ }^{4}$.

\section{Scope, objects and compensation criteria}

The law establishes a preference for the return of immovable property (as defined in Art. 142 of the Civil Code ${ }^{5}$ ), wherever return is possible. The property must either have been expropriated since 29.11 .1944 , or sequestrated on the basis of Art. 14 of Law No. 37 of 13.1.1945 on extraordinary tax for war profits and obtained after 7.4.1939 (Art. 4) ${ }^{6}$. Excluded from the scope of the law is agricultural land over 100 ha (60 ha before the 2006 amendment) (Art. 6.1). Immovable property that serves a public interest as defined in Art. 7 cannot be restituted; such interest constitutes inter alia the bulk of the cases of occupied property based on privatisation laws up to 1995 (as listed in Annex 1 of the law), which considerably restricts the scope of the restitution. However, the law explicitly includes land in tourist zones ${ }^{7}$ (Art. $6 / 1 b)$. Property which is no longer used for a public purpose must be restituted to the former owner who has to pay back any compensation received (Art. 10). The restitution of movable property is left to regulation by another law (Art. 5).

The law restitutes agricultural land up to 100 ha, if the former owner did not profit from the Law on Land of 1991; otherwise, land or compensation gained in this context must be considered in the restitution (Art. 6/1a). A building site that has been transferred to third persons is restituted to the former owner, if no permanent buildings have been legally constructed on it, while the third person is given by the State the value of the purchase multiplied by the price increase index (Art. 8.1). If permanent and legal buildings owned by the State have been constructed on the site, different rules apply: if the buildings are no longer used for used for public purposes the State has to pay rent and the former owner has the right of the first purchase. If the state-owned buildings are legally used by third parties and the value of the investment is more than $150 \%$ of the value of the building site, the third party shall pay to the State within six months the value of the building site at the market price and the State shall pay the building site value to the former owner. Otherwise the building site is to be restituted to the latter, who has the right of the first purchase after expiration of the contract. If the investment is less than $150 \%$ of the value of the building site, the property is restituted to the former owner, who has the right of the first purchase (Art. 8/1) ${ }^{8}$.

Where restitution is not possible, the State compensates the former owners with (a) other immovable property of

\footnotetext{
${ }^{1}$ Constitution of the Republic of Albania, Law No. 8417 of 21.10.1998, as amended.

${ }^{2}$ Law No. 9235 of 29.7.2004 on the restitution and compensation of immovable property, as amended.

3 See also World Bank, p. 90

${ }^{4}$ By Law No. 9388 of 4.5.2005, which extended the deadlines for the submission of requests, by Law No. 9583 of 17.7.2006, which basically extended the kind and size of the property to be restituted and changed the institutional framework for the implementation of the law, and by Law No. 9684 of 6.2.2007, which detailed the procedures to be applied. The fourth amendment, Law No. 9898 of 10.4.2008 "on some additions and changes to Law No. 9235, dated 29.7.2004 "on the restitution and compensation of property" as amended", which had been initiated by an MP of the Republican Party, extended once more the deadline for the submission of documents.

5 The Civil Code, Law No. 7850 of 29.7.1994, as amended, was adopted in 1994

${ }^{6}$ The second case was inserted by the 2006 amendment (though a similar provision inserted in the restitution law of 1993 had been declared unconstitutional by the Constitutional Court in Decision No.16 of 17.4.2000).

${ }^{7}$ On the basis of Law No. 7665 of 21.1.1993 on the development of zones with tourism as priority, as amended.

${ }^{8}$ Art. 9, which provided that flats leased before the entry into force of the Law on the Privatisation of Flats of 1992 are restituted to the former owners, if the housing needs of the tenants are met in any way possible, was abrogated by the Constitutional Court in Decision No. 11 of 4.4.2007. Previously, the Constitutional Court had abrogated Art. 9.1 with the same wording in Decision No. 26 of 2.11.2005 of for violating the principle of legal security, but it was reintroduced in the 2006 amendment.
} 
the same type of equal value in State ownership; (a/1) public immovable property located in zones with tourism development as priority; (b) other immovable property of any type of equal value in State ownership; (c) shares in companies with State capital or where the State is co-owner with a value equal to the immovable property; $(c)$ the value of objects that are subject to the process of privatisation; or (d) money exempt from fees and taxes (Art. 11). The immovable property used for compensation may be located outside the administrative-territorial borders of the region of the original immovable property (Art. 12).

The value of the property that is compensated according to this law is calculated on the basis of the market value in accordance with the methodology proposed by the PRCA and approved by a decision of the Assembly (Art. 13.2) ${ }^{9}$. The valuation of the property is done by an expert group consisting of experienced and specially qualified persons in the fields of law, economics and engineering and established by the Regional Office (Art. 13.1). Regarding immovable property occupied by the State, the former owners have the right of the first purchase, to be detailed in sub-legal acts of the Council of Ministers and registered in the Office for the Registration of Immovable Property (Art. 14). Any restitution or compensation gained, based on another law, must be considered (Art. 6.3).

Religious communities have the same rights as private individuals in matters of property restitution or compensation. However, before the amendment of 2006 which extended the size of the property to be restituted to 100 ha, the religious communities questioned the law's limitation on property restitution to 150 acres (approximately 56 ha) ${ }^{10}$.

\section{The Complex Legal Framework}

\subsection{Property restitution}

The legal situation governing immovable property in Albania is very complex. One of the reasons for this is that restitution legislation rather reflects the political orientation of the government in power, which tends to take into consideration the interests of either the pre-1945 owners (former owners) or the new (post-1991) owners. Since the first post-communist elections in 1991, in which the SP won a majority of votes, there have been three changes in government (1992 democratic majority, 1997 socialist one, 2005 again democratic).

Restitution of immovable property cannot be granted, if the property on which buildings have been illegally constructed is involved in the legalisation process, until the legal time-limitations for the legalisation of buildings in informal zones and other informal objects located within formal territories have expired (see for a definition of these terms in the annex); however, the former owner can opt for compensation (Art. 28/1.1 of the Law on Restitution and Compensation of 2004). This restriction does not apply to immovable properties which have been put by the State at the disposal of third parties by leasing, emphyteose or concession, etc., regardless of the improvements or buildings constructed on them (Art. 28/1.2 of the Law on Restitution and Compensation 2004). Basically, the Law on Legalisation of $2004^{11}$ created the possibility to legalise illegal constructions. The property of the land on which the building was put up was transferred against payment, payment in instalments or given into lease for a determined time period to the owner of the building, if the land was owned by the State. If it was owned by a private person, the transfer should be done according to the Civil Code. If a transfer was not realised, the owner of the land should be compensated according to the Law on Restitution and Compensation 2004 (Art. 10). In addition, another law ${ }^{12}$ provided for the legalisation of additions to buildings.

These laws were abrogated and replaced by the Law on Legalisation of $2006,{ }^{13}$ which allowed for the declaration of illegal constructions within 60 days after its entry into force; otherwise they were to be demolished (Art. 7). Following a lengthy procedure, the Council for Territorial Adjustment of the Republic of Albania issues a permit, which is registered in the cadastre (Arts. 11, 15). If there already exists a registration of the former owner, he or she is compensated by other

\footnotetext{
9 To this respect, the Assembly adopted Decision No. 183 of 28.4.2005 on the methodology of land evaluation, which determines the value of agricultural, urban and tourist land as well as buildings on the land; before the Constitutional Court had required that in compensating third persons the market value must be applied (Decision No. 12 of 21.3.2000).

10 International Religious Freedom Report 2007

${ }^{11}$ Law No. 9304 of 28.10 .2004 on the legalisation and urbanisation of informal zones.

${ }^{12}$ Law No. 9209 of 23.3.2004 on the legalisation of additions to buildings.

${ }^{13}$ Law No. 9482 of 3.4 .2006 on the legalisation, urbanisation and integration of illegal constructions, as amended.
} 
land or money (Art. 15.2) ${ }^{14}$. There are draft amendments ${ }^{15}$, which were returned to the Assembly for re-examination by the President of the Republic on 29.4.200816. Subsequently, they were discussed in the Parliamentary Committee for Economy; however, on 3.6.2008 the Assembly lacked the necessary majority to adopt the amendments, as the SP did not attend the Parliament session in protest that many of its proposals, such as those intended to avoid a curtailing of the competencies of the local authorities, had not been taken into account by the DP in the draft ${ }^{17}$. The draft amendments were adopted on 9.6.2008, as the DP reached 71 votes, while there were 15 votes against. It is reported that the amendments leave the local government units only two months to carry out the qualification of illegal constructions ${ }^{18}$.

Another reason why property cannot be restituted can be found in the privatisation process, which allegedly has been marked by irregularities. In peri- urban areas, new large-scale residential settlements appeared in the early 1990s due to the massive internal migration that took place at that time. Formally, private buildings were built on public land with no legal title. However, the residents have papers from transactions in the early 1990s that took place as the central Government was overwhelmed by the speed of internal migration between 1991 and 1994. The privatisation of agricultural land without payment, e.g. according to the Law on Land of 1991, must be verified by the Ministry of Agriculture, Food and Consumer Protection ${ }^{19}$.

Directly linked to the privatisation process, the process of registration of a piece of land in the cadastre constitutes a further impediment to restitution. As the first registration has proceeded to develop accurate maps and surveys, an extremely complex and fragmented pattern of rural and urban land holdings has been revealed. Land fragmentation hinders the application of civil law, functioning of markets and the practical use of land and property. Urban fragmentation arises from the standards of measurement applied in housing privatisation and restitution. Land parcels accompanying individual houses are limited to 300 square meters. For apartment buildings, land parcels have been created directly underneath the buildings and extending one meter from the outer walls. In both cases, the land surrounding the house or building is kept in State ownership, despite the fact that the occupants use these areas. Similarly, in many cases of restitution, a house or building and its underlying land are separated from the surrounding land, which is transferred to the former owner.

The Law on Property Registration ${ }^{20}$ provides that the Office for the Registration of Immovable Property registers the titles and other real rights on the basis of legal documents that prove the ownership (Art. 2/1). The registration is refused, if it overlaps with another property right which was registered earlier, until the issue has been resolved by the courts (Art. 27). Before recent amendments, the law established a presumption for certain documents, without considering the fact that some of these might have been falsified or issued as a result of bribery ${ }^{21}$.

Consequently, former workers have taken land under their ownership, although deprived of any relevant documentation, before the issuance of the relative legislative acts. Meanwhile, for the former owners of agricultural land the procedures were longer. At the time of the first land distribution, the former workers had taken under their ownership or just for use a big amount of land and when a former owner challenged legally its former property, the concrete property was found to belong to a former farm worker. In such cases, some necessary modifications of confines have taken place,

14 The evaluation procedure depends on the use of the construction and is explained in Art. 17.2. See, however, also Venice Commission 2007, p. 22

15 Law No. 9895 of 10.4 .2008$.

16 See for reasoning 'Topi: Pse s'dekretova ligjin për legalizimet', Nevila Perndoj, Shekulli, 2 May 2008 08:52:00, at http://www.shekulli.com.al.

17 See 'Shtyhet dekreti për legalizimet, mungojnë deputetët e djathtë', F. Braushi, Shekulli, 3 June 2008 08:08:00, at http://www.shekulli.com.al. A boycott of Parliament as a means of expressing discontent with and distrust of the policies of the governing party is not unknown to Albanian politics; for example, following the adoption of the Constitution in 1998 by an SP dominated Parliament, the DP embarked on a boycott, which however was ended in the context of the Kosovo crisis.

${ }^{18}$ Then they prepare (in cooperation with the Regional Offices of the Agency of Legalisation, Urbanisation and Integration of Informal Zones /Constructions) the data of the buildings without permit, based on digital aerial photos and on the divisions of the cadastre. Also, the law will include timelines, which provide, first, for the realisation of the process of compensation and, then, for the legalisation. After verification whether the land is registered as the property of third persons, the Agency forwards to the Government for decision the list for the compensation of the legal owners. Then the legalisation is carried out. See Kuvend, miratohet projektligji për legalizimet, Shekulli 9 qershor/ ora 20:05, http://www.shekulli.com.al/news/101/ARTICLE/26895/2008-06-09.html.

${ }^{19}$ Art. 28/2.1 of the Law on Restitution and Compensation 2004.

${ }^{20}$ Law No. 7843 of 13.7.1994 on property registration, as amended.

21 "The ownership must be considered as determined by the ownership documents according to Law No. 7501 of 19.7.1991, privatisation contracts based on Law No. 7652 of 23.12.1992, decisions of restitution commissions according to Law No. 7698 of 15.4.1993. 
but it still remains a conflictual issue until today.

Only the agrarian families that live in the countryside benefited from the provisions of the Law on Land of 1991, while the families that possessed agricultural land before 1944, but actually live in towns, did not benefit at all of the law. The same happened with the former big land owners. Moreover, the former owners of land, which once formed part of agricultural land owned by the State, would enjoy the right of compensation in value, given that they did not profit of compensation in kind from the implementation of the Law on Land of 1991. In order to regulate this category, a Decision of the Council of Ministers 22 was approved in 1992: it provided that agricultural land sequestrated in order to create farms should be distributed to the former owners, under the condition, however, that these families live in the town or district where the farm was located.

\subsection{Compensation}

The process of compensation is considered a failure, due to the absolute lack of the necessary sub-legal acts that define the ways, procedures and regulations of the compensation. These acts were never passed, except from certain acts that regulate compensation issues for coastal areas or other tourist zones that in reality were used mostly for abusive reasons (political/economic interests and corruption) than for solving the problem itself.

According to a certain opinion, the lack of sub-legal acts led to the implementation of the compensation process only in exceptional cases, connected with personal interests of certain "vip" individuals, members of Restitution and Compensation Property Commissions, etc. In these cases, the compensation took place in kind (land), whereas other forms of compensation (stocks etc) were never implemented. Therefore, the majority of former owners, even though they have been holding for many years the favourable decisions of the respective commissions, have never benefited from any form of compensation.

Another important question is the illegally constructed buildings. In certain zones of the periphery of Tirana as well as in other urban centres, entire districts have been created in this way. These buildings have been constructed on State and on private land. The private land was restituted to the former owners with the decisions of the Commissions on the property restitution and it was registered as such at the Registration Offices. However, this land never returned under the possession of the former owners, because it was illegally occupied and covered with buildings.

After the approval of the Law on Legalisation, all these illegal buildings will be legalised in favour of the constructors. According to legal procedures, the land where buildings have been illegally constructed will change ownership from the former owner to the constructor, whereas the former owner will be compensated. However, until today, no sub-legal act or any concrete and detailed procedure has been issued. Moreover, there are no provisions on the form, value and time of the compensation to be given to former owners, whose properties have been occupied with illegal buildings.

Issues related to property restitution and compensation.

- Approval of delayed property restitution policies;

- Uncertain and unpredictable policy for the return of property;

- Weak institutional capacity to implement the policy;

- Appearance of conflict of rights on the same property;

- Inefficient compensation systems.

\section{Recomendation}

We should continue to use the traditional monitoring mechanisms and conditionality systems to assess the extent to which the state has implemented policies to address the issue of property restitution. In this process the state should not limit its assessment to the review of legislation, but should also request concrete action plans with clear benchmarks, budgetary allocations and responsible institutions, once the national governments adopted a law. In other words, the state cannot impose a solution on this society, but once such a solution is agreed by the legitimate authorities of the state, it can request that the government and the administration do not undermine the policy through implementation flaws.

${ }^{22}$ Decision of Council of Ministers no. 452/17.10.1992, as amended by Decision of Council of Ministers no. 161/08.04.1993 "on the Restructuration of Agricultural Farms". 
This would be a good strategy aware of a well-known phenomenon: it is often easier for the national voters and the public to make the government embrace the broad principles of a policy, and even to adopt a law, but much more difficult to monitor their bureaucratic implementation. External monitoring on the administrative performance in this field, as well as the performance and fairness of other structures, such as the judiciary, which play a role in the process of property restitution, may be an important contribution to an increased level of accountability in that country, and thus a tool to improve the quality of governance. On the particular case of property restitution, the solutions do not come without significant costs (which in any case would be lower if restitution in kind would be the solution adopted by the countries). In this context the state EU may explore together with other actors of society a mechanism for financing such costs in a manner which is both practical and morally acceptable. Various arrangements may be considered, from linking restitution with the privatization process, to mutual funds, selling of state assets, special purpose loans, etc. Due consideration must also be given to the implications for the national budgetary deficit likely to be impacted.

Several problems stood out in relation to private property issues, such as:

- the lack of transparency and accuracy in legal provisions on property rights, which has favoured the development of corrupt practices across the sector;

- the large proportion of all claims brought to the People's Advocate which concern potential breaches of property rights;

- the lack of progress regarding the restitution of religious communities' property;

- the delay in the completion of immovable property records;

- the lack of an inventory of public land to be used in the restitution process;

- the lack of transparency and the inefficiency of the land legalisation process, despite assigning an increasing number of personnel to work on it;

- the inefficient results of the agency for the control of property titles, whose activity led to delays in transactions on the real estate market;

- the lack of development of a stable real estate market, due to private property rights issues.

\section{Conclusion}

The efficient development of the restitution process faces several obstacles. A report of the Property Restitution and Compensation Agency issued in October 2009 for the use of the Prime Minister's office shows that the Agency had taken no decisions after the 1 st of July 2009 , since the deadline stated in the law had not yet been postponed. This means that besides new claims the AKKP will have to provide an answer to pending claims the administrative investigation of which has not yet been finalized. Usually claims are still pending due to missing documents or procedural mistakes which impeded or delayed the adoption of a final decision. However, human resources are not available to speed up the process or support better communication to beneficiaries. Actually, the number of requests is already too large for the current administration to handle. Thus, it is highly recommended for the next phase of the process to look into ways in which more human resources could be allocated to its management. This should be part of a larger process focused on raising the administrative capacity of the institutions that implement the restitution process.

The lack of personnel is reflected in the number of judicial appeals on property restitution issues. As noted above, only one third of all appeals were dealt with, and that reflects a low capacity, to a large extent due to the lack of trained personnel. This issue needs to be addressed by future reform plans.

Making the process of evaluation of restitution claims more efficient is crucial, since unsolved claims end up in judicial courts. As mentioned earlier, between August and October 2009, 187 lawsuits were initiated against the Agency's decisions. Even though the State Advocate is the competent institution to defend in a court of law the property of the state or the legality of decisions made by its institutions, the Agency has to have its own legal representation. Thus, the demand for highly trained staff increases even more.

The change of political power directly affects the institutional setup designed to ensure property restitution. The employees of the Agency do not enjoy civil servant status. Thus, they can be replaced once the party in power changes. This is the situation of the leadership position of the Agency, which has been occupied by four different people in five years. Allegations of corruption, as well as political changes, have led to their replacement. The changes in the statute and structure of the Agency also generate ambiguity, making the institution as a whole highly unstable.

Further, the decisions of the Agency have related only to the restitution of property rights accompanied by cash compensation. As mentioned before, a property fund out of which compensation in kind could be made does not yet exist. Five years after the adoption of the current law on restitution and compensation, despite additional legal acts that aimed 
at clarifying the procedure, restitution in kind had never been made.

According to the law, property used in the public interest cannot be returned to its owners. This required initial registration of immovable property that could be used for restitution all over the country. The Albanian Assembly took a recent decision to verify property titles, including those belonging to the State. The institution in charge identified a high level of uncertainty related to registered titles, including the ones in state ownership. Thus, setting up a Property Fund based on the records of the Immovable Property Registration Office is not quite legally secure.

A yearly fund for cash compensation was included in the state budget. For 2009 this fund reached 10 million Euros and it was used to cover compensations for 211 of the 521 owners who had their property rights restored that year.

The compensation process is made according to the distribution of the claimed land across the value maps of the Agency. These maps need to be continually updated by the final compensation deadline in 2015. Considering the dynamics of the real estate market and of the number of filled and solved claims, the budget needed to cover compensation can be expected to grow. The government should take that into consideration for the elaboration of the national yearly budget.

\section{References}

Constitution of Albania, adopted on November 28, 1998

Law $37 / 1945$

Law no. 4626, dated 24.12.1969, published in the Përmbledhës i Përgjithshëm I Legjislacionit në Fuqi të Republikës Popullore Socialiste të Shqipërisë, 1945-1985.

Volume 1, Publication of the Juridical Bureau of the Council of Ministers apparatus, Tirana 1986, pg. 255

Law no. 5506, dated 28.12.1976, published in the Përmbledhës i Përgjithshëm I Legjislacionit në Fuqi të Republikës Popullore Socialiste të Shqipërisë, 1945-1985 Volume 1, Publication of the Juridical Bureau of the Council of Ministers apparatus, Tirana 1986, pg. 9.

Law No. 7491 of 29.4.1991 on the major constitutional provisions, as amended

Law No. 7512 of 10.8 .1991 on the regulation and the protection of private property, free initiative, private and independent economic activity and privatisation, as amended

Law No. 7501/1991, published in Official Journal no 5/1991, pg. 246.

Law No. 7652 of 23.12.1992 on the privatisation of state-owned flats

Law no.8312, of 26.3.1993, on undivided agricultural land

Law No.7848 dated 25.7.1994 on Expropriations in the public interest and acquisitions of immovable properties for temporary users

Law No. 7983, of 27.7.1995 on purchasing agricultural land, pastures and meadows

Law No. 8053, of 21.12.1995, on transfer of agricultural land in ownership without payment

Law no.8337, of 30.4.1998, on transferring into ownership the agricultural land, pastures and meadows

Law 7051/1999

Law 9235/2004, on restitution and compensation of property, amended

Law 10.207 dated 20.1.2010, published in official journal 194, December 2009.

Decree no. 4494/ Dated 31.3.1969

Decision of the Constitutional Court no 16 , dated 17.4.2000

Decision No. 452, of 17.10.1992, on Restructuring of agricultural enterprises

Decision of the Assembly of the Republic of Albania No. 183, on the approval of the methodology on the valuation of immovable property that will be compensated and of the methodology to be used for compensation, Official Journal 33/2005, pg. 1219; published on 18.05.2005.

Decision 566/2006 of the Council of Ministers, on the organisation and functioning of the Property Restitution and Compensation Agency. See http://www.akkp.gov.al/

Decision of the Council of Ministers No. 816, dated 20.12.2006, for the approval of the prices for building sites, defined on the relevant map, for Tirana city and Kavaja district, published in the Official Journal no. 143, dated 30.12.2006.

Decision 747/2006 of the Council of Ministers, published in Official Journal no. 121, dated 24.11.1006, pg. 4829. See Decision 653, dated 29.9.2007, For the approval of the prices for building sites as determined on the relevant maps, for the regions of Lezha, Dibra, Korca and Kukes,

Decision Nr.139, dated 13.2.2008 For the approval of the prices for building cites as determined on the relevant maps, for the regions of Fieri, Elbasan, Tirana, Vlora, Durres and Shkodra, regions. Published in the Official Journal no. 25, dated 25.02.2008.

Decision 1620/2008, Published in the Official Journal no. 196, dated 7.01.2009. 